\title{
KRITÉRIA PRO NÁRODNÍ CERTIFIKAČNÍ SYSTÉM BUDOV SBTOOLCZ
}

\section{CRITERIA for National Rating SyStem for BUILDINGS SBTOOLCZ}

\author{
Daniel Macek \\ Faculty of Civil Engineering, CTU in Prague, Thákurova 7, 16629 Prague 6, Czech Republic, \\ daniel.macek@fsv.cvut.cz, +4-202-435-4529
}

\begin{abstract}
Abstrakt
Certifikace budov je trendem v oblasti šetrných budov. Mezi světově nejuznávanější patří americký certifikační systém LEED a britský certifikační systém BREEAM. Certifikace budov by měla co nejlépe vystihnout podmínky $v$ př́slušné lokalitě, respektive zemi. Z těchto důvodů jsou vyvíjeny národní certifikační systémy. $V$ České republice existuje národní certifikační systém SBToolCZ. Původně byly certifikační systémy zaměřeny na novou výstavbu, ale z důvodů zájmu o certifikaci již realizovaných staveb, se certifikační metody začaly zaměřovat i tímto směrem. Pro tyto účely je potřeba změnit a přizpůsobit hodnotící kritéria pro provoz budov. Příspěvek se zabývá problematikou stanovení kritérií pro provoz budov v certifikačním systému SBTooICZ. Konkrétně se jedná o oblasti hodnocení facility managementu a uživatelské dokumentace budovy.
\end{abstract}

\section{Klíčová slova}

Certifikace; facility management; uživatelská dokumentace

\begin{abstract}
The building certification is a trend in green buildings. The American LEED certification system and the British BREEM certification system are the most respected in the world. But the building certification should be adapted to individual conditions in countries. For these reasons, national certification systems are being developed. There is a national certification system SBToolCZ in the Czech Republic. The certification systems were focused on new construction originally. There is a interest in the certification of completed buildings. The certification methods began to focus in this direction. It is necessary to change and adapt the assessment criteria for the operation of buildings for these purposes. The paper deals with the issue of setting criteria for building operations in the SBToolCZ certification system. The paper is specifically concerned to areas of facility management assessment and building documentation.
\end{abstract}

\section{Keywords}

Certification; facility management; user documentation

JEL Classification L74, O32

DOI: https://doi.org/10.14311/bit.2016.02.01

Editorial information: journal Business \& IT, ISSN 2570-7434, CreativeCommons license (c) (1) published by CTU in Prague, 2016, http://bit.fsv.cvut.cz/ 


\section{Úvod}

Šetrná budova neboli tzv. „Green Building” je budova, která se vyznačuje vysokou šetrností k životnímu prostředí a efektivním využíváním přírodních zdrojů po celý životní cyklus stavby, přičemž klade i vysoký důraz na uživatelský komfort. Tento typ staveb můžeme označit jako "udržitelná", „šetrná“ či „certifikovaná” budova. Šetrnou budovu charakterizuje mnoho aspektů vycházejících ze zásad trvale udržitelného rozvoje. Hlavní zásadou udržitelného rozvoje je především rovnováha mezi třemi základními oblastmi - životním prostředím, sociálními aspekty a ekonomickými aspekty. Šetrné budovy jsou navrhovány tak, aby dosahovaly co nejefektivnější vyváženosti mezi těmito faktory [1].

Neexistuje jasná definice pro přesný popis termínu „Green Building“. Definovat by se tento termín dal prostřednictvím certifikačního systému prokazujícího udržitelnost budovy, bez kterého se termín „Green Building“ nesmí použít [5]. Avšak certifikační systém není pouze jeden, nýbrž celé desítky vyvinuté $v$ různých státech po celém světě. Každý ze systémů přizpůsobuje dané podmínky a kritéria hodnocení dle charakteristik daného státu či území vycházejících z geografického umístění, možností využití prrírodních zdrojů, národních zákonů a norem či zvyklostí. Je tedy zřejmé, že budova certifikovaná dle systému z Austrálie bude mít oproti budově $s$ Evropskou certifikací odlišné některé vlastnosti, např́klad právě proto, že v Austrálii je velký nedostatek vody a místní certifikace tomuto faktu dává vyšší váhu $[3,4]$. Certifikační systémy se tedy liší ve svých podmínkách a hodnotících kritériích pro získání šetrného certifikátu, ale také v procesu, který je potřeba absolvovat. Základní kritéria a podmínky mají téměř všechny certifikace stejné, tj. podpora obnovitelných zdrojů a jejich efektivní využití, vysoce využitelné nakládání s vodou, udržitelnost použitých materiálů a vysoká kvalita vnitřního prostředí $[8,15]$.

Každý investor či developer si může vybrat, kterou z certifikací bude chtít pro návrh budovy použít. Pokud bude budova sloužit pro vlastní využití, vyberou si certifikaci, která jim bude co nejvíce vyhovovat např. dle oboru podnikání. $V$ prípadě, že má investor záměr budovu po realizaci prodat či pronajímat, bude ho více zajímat poptávka trhu $[9,13]$. Certifikační systém může také určit budoucí většinový nájemce, jenž má s investorem projektu uzavřenou předběžnou nájemní smlouvu na pronajímané plochy kancelářské budovy. Velkou roli při výběru hodnotící metody hraje také „napasování" certifikátu na daný projekt, dle návrhu může projekt splňovat různá ohodnocení dle různých certifikací [14]. Certifikovat se dají nové budovy, tj. budovy již projektované dle charakteristik pro získání určitého certifikátu, nebo také budovy již postavené, rekonstruované či uzavřené celky vnitřních prostor budovy, např. pouze kancelářské prostory [10]. V současné době se hovoří o systému definujícím zatím nejnovější měření udržitelnosti, jímž Ize certifikovat nejen budovy, ale také celé městské části, infastruktury či krajinu [2].

SBTooICZ je český certifikační nástroj pro hodnocení kvality budov. Proces certifikace byl oficiálně představen v červnu roku 2010 [7]. Výhody certifikace SBToolCZ spočívají v lokalizaci přímo na české prostředí a jako jediný plně reflektuje místní klimatické, stavební a legislativní poměry. $V$ porovnání se zahraničními certifikáty je SBToolCZ levnější a je veden v češtině. SBToolCZ vychází z mezinárodně uznávané metody a hodnotí velmi podobná kritéria jako ostatní zahraniční metody [11].

\section{Metodologie a cíle}

Cílem práce je vydefinovat hodnotící kritéria pro certifikační systém SBToolCZ v oblasti facility managementu a uživatelská dokumentace pro administrativní budovy ve fázi provozu.

Pro vypracování návrhu struktury hodnotících kritérií se vychází z analýzy světově nejuznávanějších certifikačních systémů jako je americký LEED, britský BREEAM a německý DGNB. Každý certifikační 
systém je koncipovaný a strukturovaný jiným způsobem, tudíz bylo potřeba certifikační systémy projít napríč hodnotícím systémem a vytipovat oblasti, které by se mohly týkat dané problematiky.

Zanalyzované výstupy bylo potřeba vyhodnotit v kontextu certifikačního systému SBToolCZ a vhodně doplnit o vlastní zkušenosti hodnocení kvality facility managementu a projektové dokumentace.

\section{Výsledky}

V této kapitole jsou popsány hodnotící kritéria ve struktuře, která odpovídá šabloně pro systém formálního zpracování príruček hodnocení certifikačního systému SBTooICZ. Nejdříve bude popsáno hodnoticí kritérium pro facility management a posléze hodnotící kritérium pro uživatelskou dokumentaci.

\section{Hodnotící kritérium facility management}

Efektivní facility management je nezbytnou podmínkou pro hospodárný provoz budov při zajištění stanovené kvality služeb. Dopad není jen v ekonomické, ale také v environmentální oblasti. Z pohledu činností týkajících se provozu budovy jde především o údržbu a obnovu objektu, úklid objektu a hospodaření s energiemi. Důležité informace pro optimalizaci provozu může facilty manažer získat ve zpětné vazbě od uživatelů budovy [12].

\section{Indikátor}

Posouzení stavu a provádění plánované údržby budovy. Management nákupů energií. Úklid ekologicky šetrnými prostředky a požadavky na úklidová zařízení. Zpětná vazba od uživatelů budovy.

\section{Kontext}

Facility management je oblast řízení, která zajištuje provoz a rozvoj infrastruktury a souvisejících služeb, které podporují a zvyšují efektivnost hlavních procesů organizace. Zahrnuje správu budov, správu infrastruktury organizace, nákup podpůrných služeb a celkové slad'ování pracovního prostředí organizace. Facility management tedy zajištuje správu a rozvoj pracovního prostředí. Má úzkou vazbu na řízení lidských zdrojů, management organizace a řízení služeb. Často je pojem Facility management chybně spojován pouze s externím zajištěním těchto služeb (tzv. outsourcingem), nicméně pro samotný facility management nezáleží na tom, zdali jsou tyto procesy zajištovány formou outsourcingu nebo zdali si organizace související procesy či služby zajištujuje sama. Vzhledem k tomu, že každý podnik, každá organizace má nějakou infrastrukturu, majetek či pracovní prostředí, týká se facility management $v$ nějaké své podobě každého podniku. Základní norma $v$ oblasti Facility managementu je ČSN EN 15221.

\section{Popis hodnocení}

Posouzení stavu budovy je nezbytným předpokladem pro stanovení efektivního plánu údržbových prací pro jednotlivá zařízení a konstrukční prvky budovy. Cílem je předcházet havarijním stavům jak na budově, tak i na technických zařízeních. Důležitá je i realizace nápravy zjištěných nedostatků. Kritérium odpovídá na otázku, zda bylo $v$ uplynulých 5 letech dokončeno šetření stavu budovy a zařízení, a zda byly realizovány práce k nápravě zjištěných závad? Bodové ohodnocení odpovědi je $v$ tabulce 1. Pro kontrolu vyhodnocení kritéria je potřeba předložit záznamy z provedeného průzkumu stavu, kopii akčního plánu odstranění problémů / závad, doložení provedených řešení problémů a závad, případné doložení dokumentů prokazující stáří budovy, pokud je menší než 5 let. Management nákupu energií souvisí s otázkou sledování a analýzy spotřeb energií a od toho se odvíjející odhad na budoucí potřeby zajištění dodávek energií. V tabulce 2 jsou uvedeny hodnotící parametry, které se při splnění sčítají. Pro ověření hodnocení se dokládá přehled využitých softwarových nástrojů, 
vypracované analýzy spotřeby energií, dokument strategie potřeb energií, dokumentace systému měření a regulace. Úklid ekologicky šetrnými prostředky je hodnocen v tabulce 3 . Kredit Ize získat, pokud minimálně $75 \%$ nákladů na čisticí prostředky je vynaloženo na mezinárodně nebo národně certifikované EKO produkty. Kritérium se dokládá každoroční auditní zprávou. Pro napájená jsou požadovány následující funkce:

- ochranná opatření, jako jsou válce nebo gumové nárazníky, aby nedošlo k poškození stavebních ploch;

- ergonomický design pro minimalizaci vibrací, šumu a únavy uživatelů, jak je uvedeno v uživatelské príručce podle normy ISO 5349-1 pro vibrace ramen, ISO 2631-1 pro vibrace na celé tělo a ISO 11201 pro akustický tlak u ucha obsluhy

- vakuové programy a pracují s maximální hladinou akustického tlaku 70 dBA nebo méně v souladu s normou ISO 11201

- zařizení musí být $v$ energetické třídě $A$ nebo $B$

Kontrolou je předložení soupisu používaných zařízení s vyznačením, které parametry splňují či nesplňují. Dále bude doložen plán na vyřazení stávajících zařízení na konci jejich životnosti, která kritéria nesplňují. Ve zpětné vazbě od uživatelů objektu se hodnotí, zda probíhá komunikace $s$ uživateli budovy na otázky provozu. Zjištěné informace je posléze potřeba interpretovat vedení, aby mohly být připraveny a realizovány kroky ke zlepšení provozu. Kritérium je uvedeno v tabulce 4. Prokázání splnění kritéria je možné např. pomocí zápisů z jednání, formulářu zpětné vazby nebo výpisů elektronické formy zpětné vazby.

Tabulka 1: Hodnocení posouzení a stavu budovy (zdroj: autor)

\begin{tabular}{|l|c|}
\hline Požadavek na posouzení a stav budovy & Kredity K1 \\
\hline Budova je starší 5 let a zjištování stavu nebylo provedeno v rámci posledních 5 let & 0 \\
\hline $\begin{array}{l}\text { Byla provedena prověrka stavu, nicméně nebyly provedeny žádné práce k odstranění } \\
\text { zjištěných problémů / závad }\end{array}$ & 0 \\
\hline $\begin{array}{l}\text { Byl proveden průzkum stavu a byl zaveden akční plán, který stanoví, kdy budou } \\
\text { problémy odstraněny }\end{array}$ & 1 \\
\hline Byla provedena prověrka stavu a všechny hlavní problémy / závady byly opraveny & 2 \\
\hline $\begin{array}{l}\text { Byla provedena prověrka stavu a všechny hlavní problémy / závady byly opraveny a } \\
\text { byl zaveden akční plán, kdy budou odstraněny zbývající problémy }\end{array}$ & 3 \\
\hline Bylo provedeno zjištování stavu a všechny zjištěné problémy / závady byly opraveny & 4 \\
\hline Budova není starší než 5 let a nebylo provedeno žádné zjištótóní stavu & 4 \\
\hline
\end{tabular}

Pozn.: Kredity K1 se navzájem v položkách vylučují.

Tabulka 2: Hodnocení managementu nákupu energií (zdroj: autor)

\begin{tabular}{|l|c|}
\hline Požadavek na management nákupu energií & Kredity K2 \\
\hline Použití softwarového nástroje pro sledování a analýzu dat spotřeby energií & 1 \\
\hline Pro sběr dat o spotřebě energií se používá systém měření a regulace & 2 \\
\hline Je vypracován dokument strategie potřeb energií & 1 \\
\hline
\end{tabular}

Pozn.: Kredity K2 se v položkách navzájem sčítají. Pokud výrok neplatí, pak se udělí 0 bodů.

Tabulka 3: Hodnocení úklidu ekologicky šetrnými prostředky a úklidovými zařízeními (zdroj: autor)

\begin{tabular}{|l|c|}
\hline Požadavek na úklid ekologicky šetrnými prostředky a úklidová zařízení & Kredity K3 \\
\hline $\begin{array}{l}75 \% \text { nákladů na čisticí prostředky je vynaloženo na mezinárodně nebo národně } \\
\text { certifikované EKO produkty }\end{array}$ & 1 \\
\hline $\begin{array}{l}\text { Nejméně 40\% všech poháněných zařízení musí splňovat kritéria uvedena výše. U } \\
\text { stávajících zařízení, která nesplňují kritéria, musí být vypracován plán na jejich }\end{array}$ & 1 \\
\hline
\end{tabular}


vyřazení a nahrazení ekologicky výhodnými produkty na konci jejich životnosti.

Pozn.: Kredity K3 se v položkách navzájem sčítají. Pokud výrok neplatí, pak se udělí 0 bodů.

Tabulka 4: Hodnocení zpětné vazby od uživatelů budovy (zdroj: autor)

\begin{tabular}{|l|c|}
\hline Požadavek na zpětnou vazbu od uživatelů budovy & Kredity K4 \\
\hline $\begin{array}{l}\text { Nejsou plánovány pravidelné schůzky nebo formální komunikace s uživateli objektu } \\
\text { zaměřené na získání zpětné vazby o provozu budovy }\end{array}$ & 0 \\
\hline $\begin{array}{l}\text { Jsou plánovány pravidelné schůzky nebo formální komunikace s uživateli objektu } \\
\text { zaměřené na získání zpětné vazby o provozu budovy, a zjištěné informace jsou } \\
\text { hlášeny vedení }\end{array}$ & 1 \\
\hline
\end{tabular}

Výsledný počet kreditů, který vstupuje do kriteriálních mezí se získá jako součet z udělených kreditů K1, K2, K3 a K4, tedy:

$K=K 1+K 2+K 3+K 4$

\section{Kriteriální meze}

Do kriteriálních mezí vstupuje kreditové ohodnocení posouzení a stav budovy, management nákupu energií, úklid ekologicky šetrnými prostředky a úklidovými zařízeními a zpětná vazba od uživatelů budovy.

Tabulka 5: Kriteriální meze pro kritérium facility management (zdroj: autor)

\begin{tabular}{|c|c|}
\hline Kreditové ohodnocení K & Body \\
\hline 0 & 0 \\
\hline 1 & 1 \\
\hline 2 & 2 \\
\hline 3 & 3 \\
\hline 4 & 4 \\
\hline 5 & 5 \\
\hline 6 & 6 \\
\hline 7 & 7 \\
\hline 8 & 8 \\
\hline 9 & 9 \\
\hline$\geq 10$ & 10 \\
\hline
\end{tabular}

\section{Hodnotící kritérium uživatelská dokumentace}

Hospodárné provozování budovy nelze realizovat bez dokonalé znalosti technické a stavební části budovy. $\mathrm{K}$ tomu slouží jako nezbytná pomůcka dokumentace skutečného provedení a provozní a údržbové manuály (včetně havarijních a nouzových plánů), které zachycují jak stavební části, tak technické vybavení. Informace z uvedených dokumentů neslouží jen pro provozovatele objektu z pohledu technické zprávy, ale také pro uživatele objektu, aby byli schopní budovu a zařízení v ní instalovaná efektivně využívat. $Z$ těchto důvodů je potřeba hodnotit existenci a formu těchto dokumentů [6].

\section{Indikátor}

Forma dokumentace skutečného provedení. Kompletnost provozních a údržbových příruček. Dostupnost podstatných informací z uživatelské př́ručky k budově.

\section{Kontext}

Ve stavební praxi, je základním legislativním předpisem stavební zákon č. 183/2006 Sb., v platném znění, který určuje pravidla pro stavební a územně plánovací činnosti. Ve stavebním zákoně, 
konkrétně ve vyhlášce č. 499/2006 Sb., v platném znění, je zpřesněn rozsah a obsah dokumentace skutečného provedení stavby. Tato dokumentace je pro výkon správy nemovitostí důležitou z toho důvodu, že je to poslední dokumentace, jejiž zpracování je vyžadováno orgánem státní správy a bez níž není možné vydat kolaudační souhlas. U staveb menšího rozsahu může dokumentaci nahradit kopie ověřené projektové dokumentace doplněná o výkresy odchylek, pokud to není na újmu přehlednosti a srozumitelnosti dokumentace. Po získání kolaudačního souhlasu Ize zahájit užívání objektu $\mathrm{k}$ účelu, $\mathrm{k}$ jakému byl projektován. Provozování nemovitostí je činnost spojená s řízením rutinních i nenadálých situací. Provozní dokumentace proto představuje významného společníka facility manažera, resp. správce, který je za provoz v objektu zodpovědný. Díky rádně provedené dokumentaci lze plánovat rutinní činnosti a minimalizovat, ne-li úplně se vyhnout nenadálým situacím. Dokumentace má dvě cásti: textovou a výkresovou. Platí, že pokud nelze něco vyjádřit graficky, vyjádří se to slovním popisem. Grafické vyjádření informace je preferováno z důvodu jednoznačnosti sdělení informace. DSPS komplexně postihuje celý stavebnětechnický stav objektu, proto je možné využít tuto dokumentaci pro potřeby provozu a užívání.

\section{Popis hodnocení}

Dokumentace skutečného provedení budovy je nezbytným podkladem pro efektivní správu. Forma dokumentace má vliv na rychlost a optimalizaci řešení plánovaných i vyžádaných úkonů především $v$ oblasti údržby a provozu budovy. Přidělení kreditů za tuto položku je uvedeno v tabulce. 6. Pro ohodnocení se doloží digitální nebo papírová verze dokumentace. Dalším důležitým dokumentem jsou provozní a údržbové příručky, které doplňují bližší informace o zařízeních a konstrukčních prvcích budovy a slouží pro prímý výkon údržby objektu. Hodnocení je obsaženo v tabulce 7 . Kritérium se prokazuje pomocí soupisu provozních a údržbových manuálů s kopií úvodní strany a obsahu uvedených dokumentů. Uživatele budovy by měli mít dostupné informace a pokyny jak efektivně používat budovu a zařízení, která jsou pro ně určena. Kritérium je v tabulce 8. Prokázání splnění kritéria se dokládá kopií př́slušných částí uživatelské příručky pro budovu a sdělují se podrobnosti, jakým způsobem byly informace uživatelům distribuovány.

Tabulka 6: Hodnocení formy dokumentace skutečného provedení (zdroj: autor)

\begin{tabular}{|l|c|}
\hline Požadavek na formu dokumentace skutečného provedení & Kredity K1 \\
\hline Dokumentace skutečného provedení není k dispozici & 0 \\
\hline Dokumentace skutečného provedení je k dispozici v papírové podobě & 4 \\
\hline $\begin{array}{l}\text { Dokumentace skutečného provedení je k dispozici v digitální podob̌ formou 2D } \\
\text { výkresů }\end{array}$ & 6 \\
\hline $\begin{array}{l}\text { Dokumentace skutečného provedení je k dispozici v digitální v podobě formou 3D } \\
\text { modelu }\end{array}$ & 7 \\
\hline
\end{tabular}

Pozn.: Kredity K1 se navzájem v položkách vylučují.

Tabulka 7: Hodnocení kompletnosti provozních a údržbových př́ruček (zdroj: autor)

\begin{tabular}{|l|c|}
\hline Požadavek na kompletnost provozních a údržbových příruček & Kredity K2 \\
\hline $\begin{array}{l}\text { Není k dispozici kompletní sada příruček pro provoz a údržbu, které jsou přístupny } \\
\text { zaměstnancům správy budov / zařízení }\end{array}$ & 0 \\
\hline $\begin{array}{l}\text { Je k dispozici kompletní sada príruček pro provoz a údržbu, které jsou přístupny } \\
\text { zaměstnancům správy budov / zařízení }\end{array}$ & 2 \\
\hline
\end{tabular}

Tabulka 8: Hodnocení dostupnosti podstatných informací z uživatelské příručky k budově (zdroj: autor)

\begin{tabular}{|l|c|}
\hline Požadavek na dostupnost podstatných informací z uživatelské příručky k budově & Kredity K3 \\
\hline Ne všichni uživatelé mají př́istup k podstatným informacím z uživatelské příručky k & 0 \\
\hline
\end{tabular}




\begin{tabular}{|l|c|}
\hline budově & \\
\hline $\begin{array}{l}\text { V̌̌ichni uživatelé mají př́stup k podstatným informacím z uživatelské př́ručky k } \\
\text { budově }\end{array}$ & 1 \\
\hline
\end{tabular}

Výsledný počet kreditů, který vstupuje do kriteriálních mezí se získá jako součet z udělených kreditů K1, K2 a K3, tedy:

$$
K=K 1+K 2+K 3
$$

\section{Kriteriální meze}

Do kriteriálních mezí vstupuje kreditové ohodnocení formy dokumentace skutečného provedení, kompletnosti provozních a údržbových príruček a dostupnosti podstatných informací z uživatelské príručky $\mathrm{k}$ budově.

Tabulka 9: Kriteriální meze pro kritérium uživatelská dokumentace (zdroj: autor)

\begin{tabular}{|c|c|}
\hline Kreditové ohodnocení K & Body \\
\hline 0 & 0 \\
\hline 1 & 1 \\
\hline 2 & 2 \\
\hline 3 & 3 \\
\hline 4 & 4 \\
\hline 5 & 5 \\
\hline 6 & 6 \\
\hline 7 & 7 \\
\hline 8 & 8 \\
\hline 9 & 9 \\
\hline 10 & 10 \\
\hline
\end{tabular}

\section{Závěr}

Zpracování uvedených kritérií odráží současný trend v nárocích na sytém provozování budov, jenž se neobejde bez sofistikovaného facility managementu a kvalitní a aktualizované dokumentace budovy. Snaha o certifikaci budov a plnění potřebných kritérií u budov v provozu vede $k$ zefektivnění a hospodárnosti celé správy budovy a to i v kontextu ekologické šetrnosti. Majitelé a správci budov si uvědomují důležitost provozní fáze objektu z pohledu nákladů životního cyklu budovy.

Systém certifikace musí co nejlépe vystihnout podstatu dané problematiky, aby se metoda nestala pouhým plněním dílčích kritérií a získávání potřebných bodů pro výsledné hodnocení certifikačního systému. Cílem je, aby certifikovaná budova byla opravdu pro uživatele komfortní, plnila svůj účel a zároveň byla ekonomicky efektivní s minimálním negativním dopadem na životní prostředí.

Uvedená kritérii jsou jen zlomkem z celého certifikačního systému SBTool a je potřeba je koordinovat s hodnocením ostatních oblastí, kde je možný i případný překryv. Uvedený stav je před oponentním posouzením, tudíz ve finální verzi mohou být navrženy a realizovány změny a prípadná doplnění.

\section{Poděkování}

Tento článek vznikl jako součást výzkumného projektu SGS15 / 017 / OHK1 / 1T / 11 Českého vysoké učení technického v Praze. 


\section{Literatura}

[1] DEKA, G.C. Cost-benefit analysis of datacenter consolidation using virtualization. IT Professional, 2014, 16 (6), art. no. 6964984, pp. 54-62. ISSN 15209202.

[2] DOBIÁŠ, J., MACEK, D. Leadership in Energy and Environmental Design (LEED) and its Impact on Building Operational Expenditures. Proceedings of the Creative Construction Conference 2014. Creative Construction 2014. Prague, 21.06.2014. Budapest: Diamond Congress Kft.. 2014, ISBN 978963-269-434-4.

[3] FILLIPI, M., SIROMBO, E. Green rating of existing school facilities. Energy Procedia, 2015, 78, pp. 31563161. ISSN 18766102. https://doi.org/10.1016/j.egypro.2015.11.773

[4] HROMADA, E. Decision-support tools and assessment methods. Central Europe towards Sustainable Building 2013. Praha, 26.06.2013 - 28.06.2013. Praha: Grada. 2013, pp. 669-672. ISBN 978-80-2475018-7

[5] JALAEI, F., JRADE, A. Integrating Building Information Modeling (BIM) and energy analysis tools with green building certification system to conceptually design sustainable buildings. Journal of Information Technology in Construction, 2014, 19, pp. 494-519. ISSN 14036835

[6] KARÁSEK, J. and PAVLICA, J. Green Investment Scheme: Experience and results in the Czech Republic. Energy Policy. 2016, 90(90), pp. 121-130. ISSN 0301-4215. https://doi.org/10.1016/j.enpol.2015.12.020

[7] KUBBA, S. LEED v4 Practices, Certification, and Accreditation Handbook: Second Edition, Elsevier Inc., 2015. pp. 1-675. ISBN 978012803900

[8] KUMAR, A., HANCKE, G.P. An energy-efficient smart comfort sensing system based on the IEEE 1451 standard for green buildings. IEEE Sensors Journal 2014, 14 (12), art. no. 6899588, pp. 4245-4252. ISSN 1530437X. 10.1109/JSEN.2014.2356651

[9] LIU, M.M. Probabilistic prediction of green roof energy performance under parameter uncertainty. Energy 2014, 77, pp. 667-674. ISSN: 03605442. https://doi.org/10.1016/j.energy.2014.09.043

[10] MARIQUE, A.-F., TELLER, J. Towards sustainable neighbourhoods: A new handbook and its application. WIT Transactions on Ecology and the Environment, 2014, 191, pp. 177-188. ISSN 17433541.

[11] PERI, G., RIZZO, G., GUGLIUZZA, G., VAROTTA, B. Design, building up and first results of three monitored green coverings over a university department building. Energy Procedia, 2015, 78, pp. 3037-3042. ISSN: 18766102. https://doi.org/10.1016/j.egypro.2015.11.719

[12] REDMOND, A., PAN, P. Defining techniques for developing an energy analysis services on a middleware for technical optimism of green buildings, IEEE Green Energy and Systems Conference, IGESC 2015, art. no. 7359392, pp. 61-66. ISBN: 9781467372633.

[13] QIAN, Q.K., ChAN, E.H.W., VISSCHER, H., LEHMANN, S. Modeling the green building (GB) investment decisions of developers and end-users with transaction costs (TCS) considerat. Journal of Cleaner Production, 2015, 109, pp. 315-325. ISSN 09596526.

[14] SCHNEIDEROVÁ HERALOVÁ, R. Life Cycle Cost optimization within decision making on alternative designs of public buildings. Procedia Engineering. 2014(85), pp. 454-463. ISSN 1877-7058. https://doi.org/10.1016/j.proeng.2014.10.572

[15] SUREZ, O. A comparative review of environmental concern prioritization: LEED vs other major certification systems. Journal of Environmental Management, 2015, 154, pp. 266-283. ISSN 03014797. https://doi.org/10.1016/j.jenvman.2015.02.029 